\title{
Genetic diversity within the 18S rRNA and actin locus of Cryptosporidium scrofarum (Apicomplexa: Cryptosporidiidae) infecting domestic pigs (Sus scrofa domesticus) of India
}

\author{
Devina Sharma ${ }^{1,2 *}$, Nirbhay K. Singh², Harkirat Singh ${ }^{2}$, Shitanshu S. Rath ${ }^{2}$, \\ and Damer P. Blake ${ }^{3}$ \\ ${ }^{2}$ Department of Veterinary Parasitology, College of Veterinary Science, Guru Angad Dev Veterinary and Animal \\ Sciences University, Ludhiana, India \\ ${ }^{1}$ Department of Veterinary Parasitology, DGCN College of Veterinary \& Animal Sciences, CSKHPKV, Palampur \\ Himachal Pradesh, India, India \\ ${ }^{3}$ Department of Pathobiology and Population Sciences, Royal Veterinary College, North Mymms, Hertfordshire, \\ University of London, United Kingdom
}

SHARMA, D., N. K. SINGH, H. SINGH, S. S. RATH, D. P. BLAKE: Genetic diversity within the 18S rRNA and actin locus of Cryptosporidium scrofarum (Apicomplexa: Cryptosporidiidae) infecting domestic pigs (Sus scrofa domesticus) of India. Vet. arhiv 91, 269-276, 2021.

\section{ABSTRACT}

The genetic diversity was studied of Cryptosporidium scrofarum (syn Cryptosporidium pig genotype II) of domestic pigs (Sus scrofa domesticus) from Punjab, India. Nested PCR amplification targeting the 18S rRNA and actin gene loci from Cryptosporidium positive samples was carried out, and the amplicons were sequenced. Phylogenetic comparison of a partial 18S rRNA gene revealed that they were genetically most similar to C. scrofarum isolated from other parts of the world. However, comparison of sequences representing a fragment of the genomic actin locus identified a new genotype conserved within the isolates sampled from India but distinct from other published sequences, suggesting the presence of a different Indian genotype.

Key words: actin; Cryptosporidium scrofarum; genetic diversity; pig; phylogeny; 18S rRNA

\section{Introduction}

Protozoa of the genus Cryptosporidium are apicomplexan parasites which inhabit the digestive and respiratory systems of birds, fish, reptiles, and mammals, including humans, with worldwide distribution (XIAO, 2010). Extensive genetic variation has been recorded within the genus Cryptosporidium, with 27 species and more

than 70 genotypes recognized to infect humans and/or animals (LIN et al., 2015). From pigs, six Cryptosporidium species have been isolated globally, viz., C. suis, C. parvum, C. muris, C. andersoni, $C$. scrofarum (formerly named Cryptosporidium sp. pig genotype II) and C. tyzzeri (formerly named Cryptosporidium sp. mouse genotype I) (KVAC

\footnotetext{
*Corresponding author:

Devina Sharma, Department of Veterinary Parasitology, College of Veterinary Science, Guru Angad Dev Veterinary and Animal Sciences University, Ludhiana, India, Phone: +91941845 2080; E-mail: devinasharma23@yahoo.co.in
} 
et al., 2013; YUI et al., 2014). Reports have indicated zoonotic potential for both $C$. suis and $C$. scrofarum, where humans were found to have been infected with these pig-derived Cryptosporidium species (XIAO et al., 2002; KVAC et al., 2009) Cryptosporidiosis in pigs occurs primarily through transmission by the faeco-oral route, commonly resulting in diarrhoea and weight loss, however, in neonatal and immunodeficient pigs, mortality has also been observed (BOUZID et al., 2013).

The occurrence of Cryptosporidium infections in domestic pigs (Sus scrofa domesticus) has been reported worldwide (RYAN et al., 2003; SUAREZLUENGAS et al., 2007; JOHNSON et al., 2008; CHEN et al., 2011; YIN et al., 2011; DA SILVA FIUZA et al., 2011; BUDU-AMOAKO et al., 2012; NEMEJC et al., 2013). Pigs are an important reservoir of Cryptosporidium, which thus makes it imperative to understand its prevalence in swine for the prevention and control of cryptosporidiosis in both animal and human populations. Differences have been reported in the population structure and molecular characteristics of Cryptosporidium species/genotypes in pigs between and within countries (ZHANG et al., 2013), encouraging detailed regional screening. In India, however, no published reports are available on the occurrence, molecular characterization and phylogenetic analysis of pig-derived Cryptosporidium isolates. Therefore, the present study aimed to characterize Cryptosporidium sp. and identify the genetic diversity at the $18 \mathrm{~S}$ rRNA and actin gene loci.

\section{Materials and methods}

Collection and coproscopic examination. Faecal samples $(\mathrm{n}=839)$ were collected from apparently healthy pigs from 36 organised or backyard pig farms in Punjab State, India. The faecal samples were subjected to routine coprological studies, and samples $(n=43)$ positive for coccidian oocysts were transported to the Royal Veterinary College for molecular characterisation studies. These were screened for concurrent Cryptosporidium infection by a modified Ziehl Neelsen staining technique (BHAT et al., 2014) and nested polymerase chain reaction at two gene loci, viz. the $18 \mathrm{~S}$ rRNA and actin gene, as described below.
Subheading genomic DNA extraction. The positive samples were subjected to genomic DNA extraction, as described previously for coccidian parasites (KUMAR et al., 2014). Briefly, an aliquot of $200 \mathrm{mg}$ sample was first homogenised using a Bead Beater at 30,000 $\times$ oscillations/min for $30 \mathrm{sec}$ after adding 0.4-0.6 mm glass beads (Sigma-Aldrich, St Louis, USA) to 0.5 volume of the faecal pellet. Total genomic DNA was subsequently isolated using a QIAamp DNA Stool mini kit (Qiagen, Germany), as per the manufacturer's protocol with some modifications. Each homogenized faecal sample was mixed with $1.4 \mathrm{~mL}$ ASL buffer in a $2.0 \mathrm{~mL}$ microcentrifuge tube. The suspension was then heated for $5 \mathrm{~min}$ at $70{ }^{\circ} \mathrm{C}$ and processed as per the kit protocol. The DNA was eluted twice in $100 \mu \mathrm{L}$ Tris EDTA (TE) buffer, quantified, and the purity was checked using a Nanodrop 2000/200C spectrophotometer (Thermo Fisher Scientific, USA) and stored at $-20{ }^{\circ} \mathrm{C}$ until use.

$18 S$ rRNA gene amplification and sequencing. A fragment of the Cryptosporidium 18S rRNA gene was amplified as described by XIAO et al. (2001) using the primers

\section{Crypto F1 (5'-TTCTAGAGCTAATACATGCG-3')}

and

Crypto R1 5'-CCCATTTCCTTCGAAACAGGA-3'), followed by

Crypto iF2 5'-GGAAGGGTTGTATTTATTAGATAAAG-3') and

\section{Crypto iR2}

\section{(5'-AAGGAGTAAGGAACAACCTCCA-3').}

Each reaction was performed in a final volume of $25 \mu \mathrm{L}$ in a thermal cycler (Applied Biosystems ${ }^{\mathrm{TM}}$ SimpliAmp $\left.{ }^{\mathrm{TM}}\right)$. In the primary assay $2.5 \mu \mathrm{L}(\sim 2-$ $20 \mathrm{ng} / \mu \mathrm{L}$ ) genomic DNA was used as template, together with $400 \mathrm{nM}$ forward and reverse primers, and $12.5 \mu \mathrm{L}$ of $2 \times$ MyTaq $^{\mathrm{TM}} \mathrm{Mix}$ (Bioline, Taunton, USA), made up to $25 \mu \mathrm{L}$ with nuclease free water (Thermo-Fisher Scientific, Hemel Hempstead, UK). The PCR amplification was initiated at $94{ }^{\circ} \mathrm{C}$ for $3 \mathrm{~min}$ followed by 40 cycles of $94{ }^{\circ} \mathrm{C}$ for 30 sec, $55^{\circ} \mathrm{C}$ for $30 \mathrm{sec}, 72{ }^{\circ} \mathrm{C}$ for $1 \mathrm{~min}$ and a final elongation step at $72{ }^{\circ} \mathrm{C}$ for $7 \mathrm{~min}$. In the nested assay, $1 \mu \mathrm{L}$ of the primary PCR amplicon was used as a template, with the same reaction mixture and cycling conditions as the primary assay, other 
than substitution of the nested primers. Total genomic DNA from Cryptosporidium sp. hedgehog genotype (SANGSTER et al., 2015) and nuclease free water served as positive and negative controls, respectively. PCR amplicons were viewed on $1.0 \%$ $(\mathrm{w} / \mathrm{v})$ agarose gel stained with $0.01 \% \mathrm{SafeView}^{\mathrm{TM}}$ Nucleic Acid Stain (Novel Biological Solutions, Huntingdon, UK). Amplicons of the correct size were purified using a QIAquick ${ }^{\circledR}$ PCR Purification Kit (Qiagen, Germany) as per the manufacturer's instructions, and sequenced using the internal nested primers. The positive amplicons were subjected to two-directional sequencing, with internal primers used for nested PCR assay using the ABI Ready Reaction Mix (BigDye ${ }^{\circledR}$ Terminator v3.1 chemistry; Applied Biosystems, Foster City, USA), followed by direct automated sequencing (GATC Biotech, Cologne, Germany).

Partial actin gene amplification and sequencing. A semi-nested PCR was employed to amplify a fragment of the genomic actin locus using the primers ScrofActinFA

(5'-TGTAGGTGACGAGGCTCAATCCAA-3') and ScrofActinRA

(5'-ATCGATTGGAAAGTGGTCTCGCCA-3'), followed by ScrofActinFA and ScrofActinRB (5'-TTCTGGGCACCTAAATCTCTCGCT-3').

Each reaction was performed in a final volume of $25 \mu \mathrm{L}$ in a thermal cycler (Applied Biosystems ${ }^{\mathrm{TM}}$ SimpliAmp $\left.{ }^{\mathrm{TM}}\right)$. In the primary assay, $2.5 \mu \mathrm{L}(\sim 2-$ $20 \mathrm{ng} / \mu \mathrm{L})$ genomic DNA was used as the template, together with $400 \mathrm{nM}$ forward and reverse primers and $12.5 \mu \mathrm{L}$ of $2 \times$ MyTaq $^{\mathrm{TM}}$ Mix (Bioline, Taunton, USA), made up to $25 \mu \mathrm{L}$ with nuclease free water (Thermo-Fisher Scientific, Hemel Hempstead, UK). The PCR amplification was initiated at $94{ }^{\circ} \mathrm{C}$ for $5 \mathrm{~min}$ followed by 35 cycles of $94{ }^{\circ} \mathrm{C}$ for 45 sec, $57^{\circ} \mathrm{C}$ for $45 \mathrm{sec}, 72{ }^{\circ} \mathrm{C}$ for $1 \mathrm{~min}$, and a final elongation step at $72{ }^{\circ} \mathrm{C}$ for $10 \mathrm{~min}$. In the nested assay, $1 \mu \mathrm{L}$ of the primary PCR amplicon was used as a template with the same reaction mixture, and the cycling conditions were the same as the primary assay, other than the substitution of the nested primers, as described by KVAC et al. (2013).

Sequence analysis. Sequences were assembled and curated using CLC Main Workbench version
6, with consensus sequences annotated on the basis of BLASTn similarity using the GenBank non-redundant dataset. Related sequences from other Cryptosporidium isolates were identified, downloaded and aligned using MUSCLE, prior to phylogenetic analysis using MEGA 6.0. Molecular phylogenetic analysis was conducted using the Maximum Likelihood method in Mega 6.0 software with the Tamura 3-parameter model, based upon the optimal Akaike Information Criterion. The rate variation was modelled with a gamma distribution and invariant sites, supported by 1000 bootstrap replication. Neighbor Joining and Maximum Parsimony were run in parallel for comparison of phylogenetic stability. Sequences representing a fragment of the genomic actin locus were processed in the same way, using the General Time Reversal model with invariant sites.

\section{Results}

The nested polymerase chain reaction (PCR) analysis of the DNA extracted from the Eimeria positive samples originating from the Fazilka and Ludhiana regions of Punjab, India, resulted in amplification of a partial 18S rRNA fragment of $\sim 821$ bp. The Cryptosporidium oocysts were also identified by a modified Ziehl Neelsen staining technique (Fig. 1).

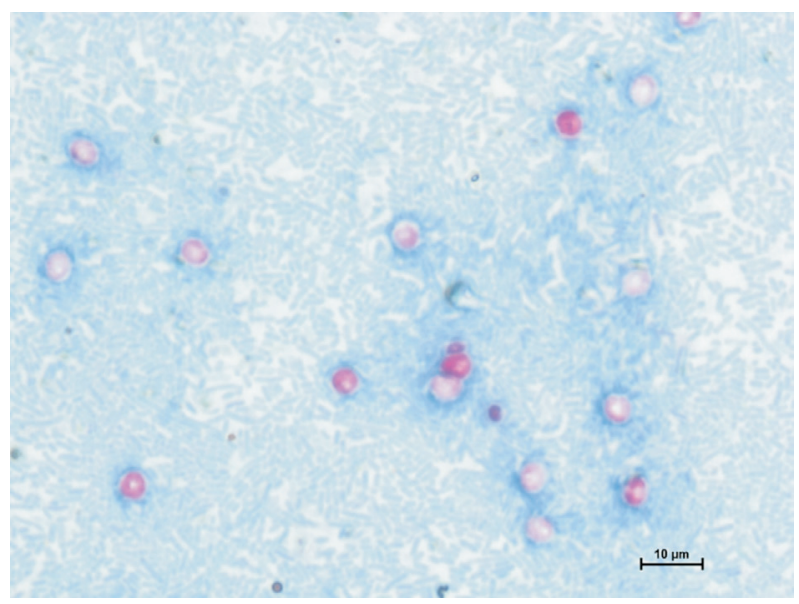

Fig. 1. Cryptosporidium oocysts by modified Zeihl Neelsen Staining, $\times 100$.

The sequencing and BLAST analysis of the amplicons revealed that they were most similar to C. scrofarum (syn Cryptosporidium genotype II). 
Phylogenetic comparison of these 18S rRNA gene sequences (accession numbers MG576146-7) from theFazilkaandLudhianaregionsofPunjab,India, with other published C. scrofarum 18S rRNA sequences, and a selection of other reference sequences, revealed a single C. scrofarum lineage (Fig. 2a).

Comparable topologies were determined using ML, NJ and MP methods. Phylogenetic comparison of $619 \mathrm{bp}$ fragments of the C. scrofarum genomic actin locus from Fazilka and Ludhiana samples (LT976831-2), with reference sequences from Japan and the Czech Republic (AB852580 and JX424841), identified two shared synonymous substitutions in both Indian sequences (Supplementary Fig. 1). An additional, unannotated sequence from Norway was also compared (EF012374), revealing two different synonymous and one non- synonymous substitutions (Supplementary figures Figs. 1 and 2). Phylogenetic comparison of the genomic actin sequences revealed a genetic distance between the Indian and the otherC. scrofarum sequences(Fig. 2b).

\section{Discussion}

RYAN et al. (2003) in their study on molecular characterization of Cryptosporidium from pigs employing 18S rRNA, identified two distinct genotypes of Cryptosporidium sp., namely genotype I (C. suis) which was previously known from pigs, and a novel pig genotype (pig genotype II). They suggested that this novel genotype warranted species status. Later, KVAC et al. (2013) proposed the species name $C$. scrofarum to reflect its prevalence in adult pigs worldwide. In the present study, C. scrofarum was identified for the first time in pigs in Punjab state, and to the best of our knowledge there are no previous reports from India. Cryptosporidiosis in pigs has occasionally been shown to result in clinical signs. In humans, the two pig-adapted Cryptosporidium species, viz. C. suis and C. scrofarum, are potentially zoonotic (XIAO et al., 2002; CAMA et al., 2003; LEONI et al., 2006; KVAC et al., 2009).

Cryptosporidium scrofarum has been also detected in an immuno-competent person, in cattle without pigs nearby, and from a potential human source (DA SILVA FIUZA et al., 2011).

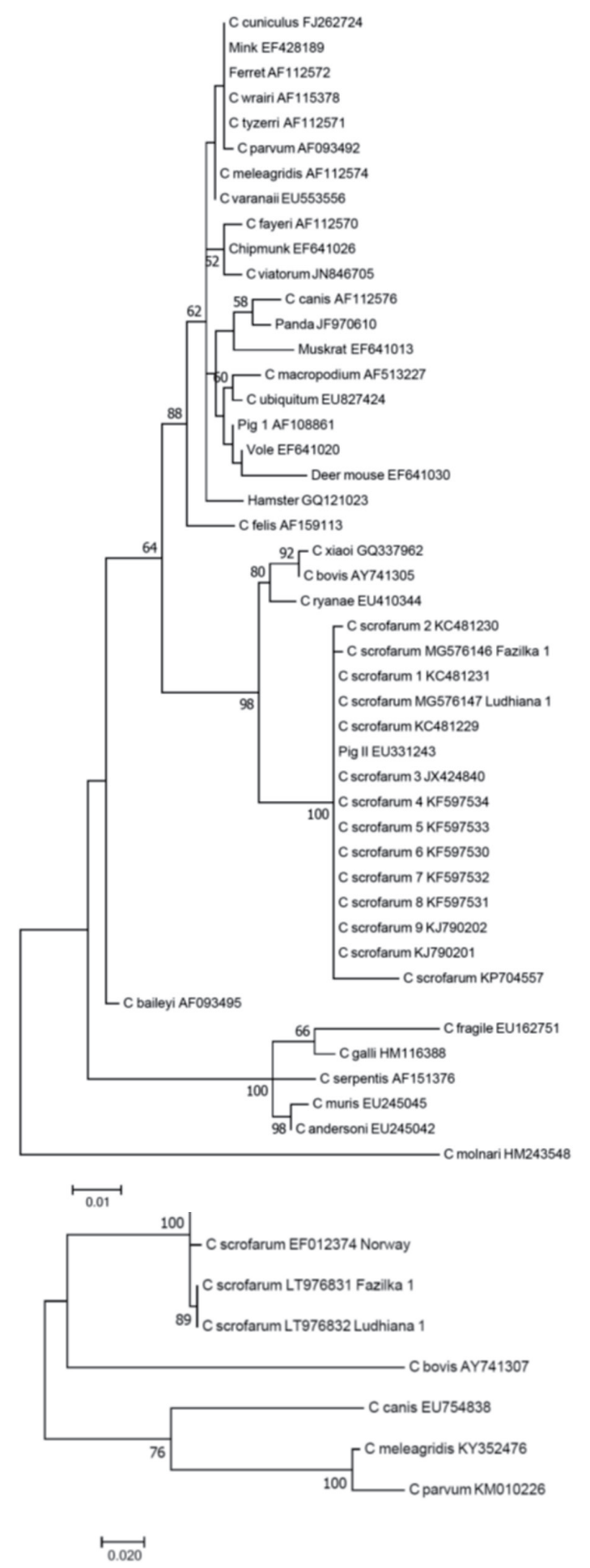

Fig. 2. Maximum Likelihood phylogenies based on partial (a) $18 \mathrm{~S}$ rDNA and (b) actin gene sequences of Cryptosporidium sp. Assemblies of 705 and 586 bp were used, respectively. Neighbor Joining and Maximum Parsimony methods provided comparable topologies. 
D. Sharma et al.: Genetic diversity within the $18 \mathrm{~S}$ rRNA and actin locus of Cryptosporidium scrofarum (Apicomplexa: Cryptosporidiidae) infecting domestic pigs of India

$\begin{array}{ccc}20 & 40 & 60 \\ 1 & 1 & 1 \\ 1 & 1 & 0\end{array}$

C_scrofarum AB852580 Japan CAA T CCAAAA GAGG T A T A T T GAC TT T GAAAT ACCC T A T T G AGCACGG TAT CAA AG T T ACGAA T T GGGAGGA T A 70 C_scrofarum_EF012374_Norway T CCAAAA GAGG T A T A T T GACT T T GAAA T ACCC T A T T G AGCACGG T A T CAA T AG T T ACGAA T T GGGAGGA T A 70 C_scrofarum_LT976831_Fazilka_1 CCAAAA GAGG T A T A T T GAC T T T GAAA T ACCC T A T T G AGCACGG TA T CAA T AG T T ACGAA T T GGGAGGA T A 70 C_scrofarum_LT976832_Ludhiana_1 CCAAAA GAGG T A T A T T GAC T T T GAAA T ACCC T A T T G AGCACGG TA T CAA T AG T T ACGAA T T GGGAGGA T A 70

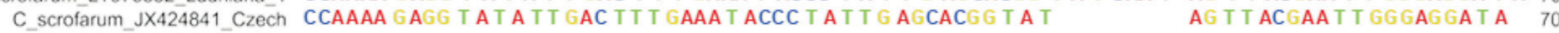

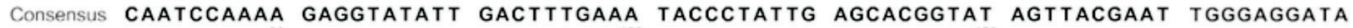
80
1

C_scrofarum_AB852580_Japan TGGAGAAGAT TTGGCATCAT ACATTTTACA ATGAGTTACG TGTCGCTCCA GAGGAGCACC CAGTATTGTI 140 C scrofarum EF012374 Norway TGGAGAAGAT TTGGCATCAT ACATTTTACA ATGAGTTACG TGTCGCTCCA GAGGAGCACC CAG TAT A T T 140 C scrofarum LT976831 Fazilka 1 TGGAGAAGAT TTGGCA TCAT ACA TTTTACA ATGAGTTACG TG TCGCTCCA GAGGAGCACC CAG T A T T T T 140 C scrofarum LT976832 Ludhiana 1 TGGAGAAGAT TTGGCA TCAT ACATTTTACA ATGAGTTACG TG TCGCTCCA GAGGAGCACC CAG T A T T T T 140

C scrofarum JX424841 Czech TGGAGAAGAT TTGGCATCAT ACATTTTACA ATGAGTTACG TGTCGCTCCA GAGGAGCACC CAGTATTGTT 140

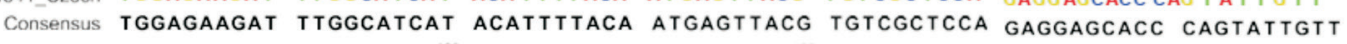
180 200

C_scrofarum_AB852580_Japan AACTGAGGCA CCGATGAATC CAAAAGTAAA TCG TGAGAGA ATGACTCAGA TAATGTTTGA GACATTCAAT 210 C_scrofarum_EF012374_Norway AACTGAGGCA CCGATGAATC CAAAAG TAAA TCG TGAGAGA ATGACTCAGA TAATGTTTGA GACATTCAAT 210 C_scrofarum_LT976831_Fazilka_1 AAC T GAGGCA CCGATAATCA C_scrofarum_LT976832_Ludhiana_1 AACTGAGGCA CCOA A C scrofarum JX424841 Czech AACTGAGGCA CCGATGAATC CAAAAGTAAA TCGTGAGAGA ATGACTCAGA TAATGTTTGAGACATTCAAT 210 Consensus AACTGAGgCA CCGATGAatC CAAAAGTAAA TCGTGAGAGA ATGACTCAGA

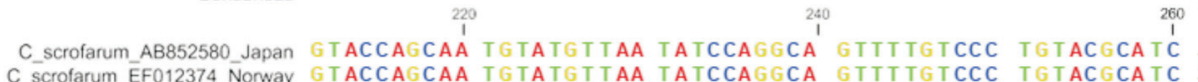
TAATGTTTGA GACATTCAAT

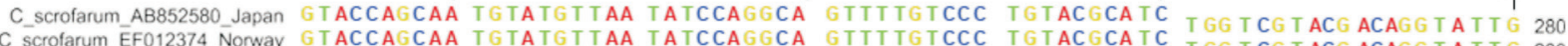
Cofrarum LT976831 Fazilka 1 GTACCAGCAA TGTATGTTAA TATCCAGGCA GTTTTGTCCC TGTACGCATC TGG TCG ACG ACAGGTATTG 280 (1) GACCAGCAA TGTATGTTAA TATCCAGGCA GTTT TGTCCC TGTACGCATC TGG TCGTACG ACAGGTATTG 280 C scrofarum JX424841 Gzech GTACCAGCAA TGTATGTTAA TATCCAGGCA GTTTTGTCCC TGTACGCATC TGG TCGTACG ACAGGTATTG 280

C scrofarum JX424841 Czech GTACCAGCAA TGTATGTTAA TATCCAGGCA GTTTTGTCCC TGTACGCATC TGG TCGTACGACAGGTATTG 280

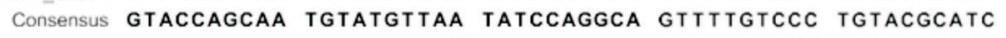

C_scrofarum_AB852580_Japan TTTTGGATAG TGGTGATGGT GTTTCACACA CAGTTCCAA I TTATGAAGGT

C_scrofarum_EF012374_Nonway TTTTGGATAG TGGTGATGGT GTCTCACACA CAG TTCCAAT
TTATGAAGG

C_scrofarum_LT976831_Fazilka_1 TTTTGGATAG TGGTGATGGT GTTTCACACA CAGTTCCAAT TTATGAAGGT

C_scrofarum_JX424841_Czech TTTTGGATAG TGGTGATGGT GTTTCACACA CAGTTCCAAT TTATGAAGGT Consensus TTTTGGATAG TGGTGATGGT GTTTCACACA CAGTTCCAAT TTATGAAGGT GGTCGTACG ACAGGTATTG 340

ATGCTCTTC CTCATGCCAT 350 ATGCTCTTC CTCATGCCAT 350 AT TCTCTTC CTCATGCCAT 350 ATGCTCTTC CTCATGCCAT 350 TATGCTCTTC CTCATGCCAT 350 TATGCTCTTC CTCATGCCAT

C_scrofarum_AB852580_Japan TATGAGATT 6 GATTTGGCTG GTCGTGACT T GACAGATTTC CTGATGAAA

C scrofarum EF012374 Nonway TATGAGATTG GATTTGGCTG GTCGTGACTT G ACAGATTTC CTGATGAAAA

C_scrofarum LT976831 Fazilka_1 TATGAGATTG GATTTGGCTG GTCGTGACTT GACAGATTTC CTGATGAAAA

C scrofarum LT976832 Ludhiana_1 TATGAGATTG GATTTGGCTG GTCGTGACTT GACAGATTTC CTGATGAAAA

C scrofarum JX424841 Czech TATGAGATTG GATTTGGCTG GTCGTGACTT GACAGATTTC CTGATGAAAA Consensus tATGAGATTG GATTTGgCTG GTCGTGACTT GACAGATTTC CTGATGAAAA

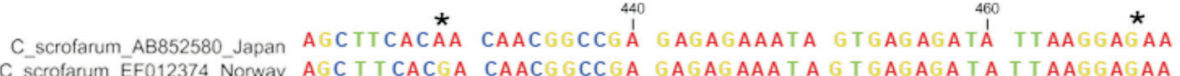

C_scrofarum_EFF012374_Norway AGC T T CACGA CAACGGCCGA GAGAGAAAT A G T GAGAGA TA T T AAGGAGAA

C_scrofarum_LT976831_Fazilka_1 AGC T T CACAA CAACGG CCGA GAGAGAAA T A G T GAGAGATA T TAAGGAAAA

C_scrofarum_LT976832 Ludhiana_1 AGC T T CACAA CAACGGCCGA GAGAGAAA TA G T GAGAGATA T TAAGGAAAA

C_scrofarum_JX424841_Czech AGCTTCACAA CAACGGCCGA GAGAGAAATAGTGAGAGA TA TTAAGGAGAA Consensus AGCTTCACAA CAACGGCCGA GAGAGAAATA GTGAGAGATA TTAAGGAGAA

C_scrofarum_AB852580_Japan ATTATGAG\# \# GGAGATGAAG AAATCTCAAG AGTCTTCTGA AATTGAGAAA

C_scrofarum_EF012374_Noway ATTATGAGAA GGAGATGAAG AAATCTCAAG AGTCTTCTGA AATTGAGAAA ACATATGAGTTGCCTGATGG 560

C scrofarum LT976831 Fazilka 1 ATTATGAGGA GGAGATGAAG AAATCTCAAG AGTCATCTGA AATTGAGAAA ACATATGAGTTGCCTGATGG 560

C_scrofarum LT976832 Ludhiana_1 ATTATGAGGA GGAGATGAAG AAATCTCAAG AGTCATCTGA AATTGAGAAA ACATATGAGTTGCCTGATGG 560

C scrofarum JX424841 Czech ATTATGAGGA GGAGATGAAG AAATCTCAAG AGTCTTCTGA AATTGAGAAA ACATATGAGTTGCCTGATGG 560 Consensus ATtATGAgga gGagatgaAg aAATCTCAAG AGTCTTCTGA AATtGagaAa 580

C.scrofarum AB852580 Japan TCACG TAATT ACCG T AGGÁ GCGAGA 586

C scrofarum ËF012374 Norway TCACG TAATT ACCG. T AGGAA GCGAGA 586

C_scrofarum_LT976831 Fazilka_1 TCACG TAATT ACCG T AGGAA GCGAGA 586

C_scrofarum_LT976832_Ludhiana_1 TCACGTAATT ACCG T AGGAA GCGAGA 586

C_scrofarum_JX424841_Czech TCACGTAATT ACCGTAGGAAGCGAGA 586

Consensus TCACGTAATT ACCGTAGgAA GCGAGA

Supplementary Fig. 1. Alignment of published and new C. scrofarum partial genomic actin locus sequences.

* = Synonymous substitution, $\#=$ Non-synonymous substitution. 


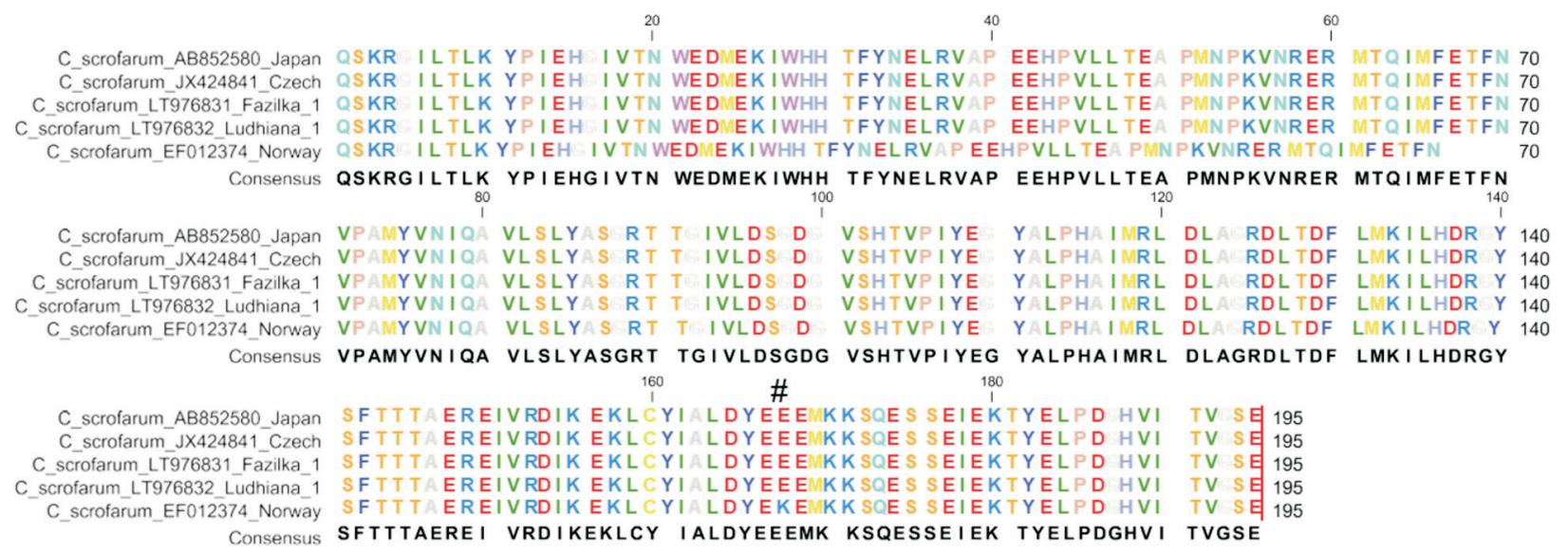

Supplementary Fig. 2. Alignment of published and new C. scrofarum predicted actin amino acid sequences. \# = Non-synonymous substitution.

Other Cryptosporidium species isolated from pigs, namely; C. suis, C. muris and C. parvum, have also been associated with zoonotic infections (YIN et al., 2011). Thus, pigs principally free roaming, pose a significant public health risk because they act as an important reservoir of Cryptosporidium sp. and can facilitate zoonotic infections via faecal contamination of water sources and the environment.

Phylogenetic comparison of a partial 18S rRNA gene fragment identified a distinct monophyletic grouping for $C$. scrofarum, most closely related to $C$. bovis, $C$. xiaoi and $C$. ryanae, but distinct from $C$. parvum and other related species in line with KVAC et al. (2013b) propose the species name Cryptosporidium scrofarum n. sp. to reflect its prevalence in adult pigs worldwide. Oocysts of C. scrofarum are morphologically indistinguishable from C parvum, measuring 4.81-5.96 lu03bcm (mean $=5.16)$. XIAO et al. (1999) has previously associated this difference with the biology of the two Cryptosporidium groups, including different predilection sites. Additional analysis using a fragment of the genomic actin locus revealed distinct differences between the Indian and all other published sequences, suggesting the presence of a different Indian genotype. Additional samples need to be sequenced for validation. Such genetic markers offer value in future studies of the occurrence, genetics and diversity of C. scrofarum.
In conclusion, we report for the first time Cryptosporidium scrofarum (syn Cryptosporidium genotype II) from pigs reared in India. Because of the asymptomatic infections caused by $C$. scrofarum and C. suis in pigs, and the close contact of domestic pigs with humans and human water sources, these parasites pose an invisible threat to human health. Further, pigs can act as reservoirs of cryptosporidiosis for onward transmission to immune-compromised individuals. Intra-species comparison of a partial actin gene fragment indicated polymorphism between samples sequenced in this and other published studies. Thus, further molecular epidemiological surveillance is required to assess transmission dynamics in pigs, and to formulate effective control strategies.

\section{Acknowledgments}

The authors are grateful to the Dean of Post-Graduate Studies, Guru Angad Dev Veterinary and Animal Science University, Ludhiana, Punjab, India, for providing the facilities to carry out the research work. Thanks are also due to the farmers who generously gave their time and hospitality. Sincere thanks to the Commonwealth Scholarship Commission for granting funds to the senior author through a Split Site PhD Scholarship (ID: INCN-2016-68) to carry out part of the work at the Royal Veterinary College, United Kingdom.

\section{References}

BHAT, S. A., M. DIXIT, P. D. JUYAL, N. K. SINGH (2014): Comparison of nested PCR and microscopy for the detection of cryptosporidiosis in bovine calves. J. Parasit. Dis. $38,101-105$.

DOI: $10.1007 / \mathrm{s} 12639-012-0201-5$ 
BOUZID, M., P. R. HUNTER, R. M. CHALMERS, K. M. TYLER (2013): Cryptosporidium pathogenicity and virulence. Clin. Microbiol. Rev. 26, 115-134.

DOI: $10.1128 /$ CMR.00076-12

BUDU-AMOAKO, E., S. J. GREENWOOD, B. R. DIXON, H. W. BARKEMA, D. HURNIK, C. ESTEY, J. T. MCCLURE (2012): Occurrence of Giardia and Cryptosporidium in pigs on Prince Edward Island, Canada. Vet. Parasitol. 184, 18-24.

DOI: 10.1016/j.vetpar.2011.07.047

CAMA, A. V., C. BERN, I. M. SULAIMAN, R. H. GILMAN, E. TICONA, A. VIVAR, V. KAWAI, D. VARGAS, L. ZHOU, L. XIAO (2003): Cryptosporidium species and genotypes in HIV-positive patients in Lima. J. Eukaryot. Microbiol. 50,531-533.

DOI: 10.1111/j.1550-7408.2003.tb00620.

CHEN, Z., R. MI, H. YU, Y. SHI, Y. HUANG, Y. CHEN, P. ZHOU, Y. CAI, J. LIN (2011): Prevalence of Cryptosporidium spp. in pigs in Shanghai, China. Vet. Parasitol. 181, 113-119.

DOI: 10.1016/j.vetpar.2011.04.037

DA SILVA FIUZA, V., S. GALLO, E. FRAZAO-TEIXEIRA, M. SANTIN, R. FAYER, F. C. OLIVEIRA (2011): Cryptosporidium pig genotype ii diagnosed in pigs from the State of Rio De Janeiro, Brazil. J. Parasitol. 97, 146147.

DOI:10.1016/j.vetpar.2010.10.036

JOHNSON, J., R. BUDDLE, S. REID, A. ARMSON, U. M. RYAN (2008): Prevalence of Cryptosporidium genotypes in pre and post-weaned pigs in Australia. Exp. Parasitol. 119, 418-421.

DOI: 10.1016/j.exppara.2008.04.009

KUMAR, S., R. GARG, A. MOFTAH, E. L. CLARK, S. E. MACDONALD, A. S. CHAUDHRY, O. SPARAGANO, P. S. BANERJEE, K. KUNDU, F. M. TOMLEY, D. P. BLAKE (2014): An optimised protocol for molecular identification of Eimeria from chickens. Vet. Parasitol. 199, 24-31.

DOI: $10.1016 /$ j.vetpar.2013.09.026

KVAC, M., D. KVETONOVA, B. SAK, O. DITRICH (2009): Cryptosporidium pig genotype II in immunocompetent man. Emerg. Infect. Dis. 15, 982-983.

DOI: 10.3201/eid1506.07621

KVAC, M., M. KESTRANOVA, M. PINKOVA, D. KVETONOVA, J. KALINOVA, P. WAGNEROVA, M. KOTKOVA, J. VÍTOVEC, O. DITRICH, J. MCEVOY, B. STENGER, B. SAK (2013): Cryptosporidium scrofarum n. sp. (Apicomplexa: Cryptosporidiidae) in domestic pigs (Sus scrofa). Vet. Parasitol. 191, 218-227.

DOI: 10.1016/j.vetpar.2012.09.005

LEONI, F., C. AMAR, G. NICHOLS, S. PEDRAZADIAZ, J. MCLAUCHLIN (2006): Genetic analysis of Cryptosporidium from 2414 humans with diarrhoea in
England between 1985 and 2000. J. Med. Microbiol. 55, 703-707.

DOI: $10.1099 / \mathrm{jmm} .0 .46251-0$

LIN, Q., X. Y. WANG, J. W. CHEN, L. DING, G. H. ZHAO (2015): Cryptosporidium suis infection in post-weaned and adult pigs in Shaanxi Province, Northwestern China. Korean J. Parasitol. 53, 113-117.

DOI: $10.3347 / \mathrm{kjp} .2015 .53 .1 .113$

NEMEJC, K., B. SAK, D. KVETONOVA, V. HANZAL, P. JANISZEWSKI, P. FOREJTEK, D. RAJSKÝ, P. RAVASZOVA, J. MCEVOY, M. KVAC (2013): Cryptosporidium suis and Cryptosporidium scrofarum in Eurasian wild boars (Sus scrofa) in Central Europe. Vet. Parasitol. 197, 504-508.

DOI:10.1016/j.vetpar.2013.07.003

RYAN, U. M., B. SAMARASINGHE, C. READ, J. R. BUDDLE, I. D. ROBERTSON, R. C. A. THOMPSON (2003): Identification of a novel Cryptosporidium genotype in pigs. Appl. Environ. Microbiol. 69, 3970-3974.

DOI: 10.1128/AEM.69.7.3970-3974.2003

SANGSTER, L., D.P. BLAKE, G. ROBINSON, T.C. HOPKINS, R.C. SA, A.A. CUNNINGHAM, R.M. CHALMERS, B. LAWSON (2015). Detection and molecular characterisation of Cryptosporidium parvum in British European hedgehogs (Erinaceus europaeus). Vet Parasitol. 217,39-44.

DOI: 10.1016/j.vetpar.2015.12.006.

SUAREZ-LUENGAS, L., A. ClAVEL, J. QUILEZ, M. P. GONI-CEPERO, E. TORRES, C. SANCHEZ-ACEDO, E. DEL CACHO (2007): Molecular characterization of Cryptosporidium isolates from pigs in Zaragoza (northeastern Spain). Vet. Parasitol. 148, 231-235.

DOI:10.1016/j.vetpar.2007.06.022

XIAO, L. (2010): Molecular epidemiology of cryptosporidiosis: An update. Exp. Parasitol. 124, 80-89.

DOI: 10.1016/j.exppara.2009.03.018

XIAO, L., C. BERN, M. ARROWOOD, I. SULAIMAN, L. ZHOU, V. KAWAI, A. VIVAR, A. A. LAL, R. H. GILMAN (2002). Identification of the Cryptosporidium pig genotype in a human patient. J. Infec. Dis. 185, 1846-1848.

DOI: $10.1086 / 340841$

XIAO, L., L. ESCALANTE, C. YANG, I. SULAIMAN, A. A. ESCALANTE, R. J. MONTALI, R. FAYER, A. LAL (1999): Phylogenetic analysis of Cryptosporidium parasites based on the small-subunit rRNA gene locus. Appl. Environ. Microbiol. 65, 1578-1583.

XIAO, L., A. SINGH, J. LIMOR, T. K. GRACZYK, S. GRADUS, A. LAL (2001): Molecular characterization of Cryptosporidium oocysts in samples of raw surface water and wastewater molecular characterization of Cryptosporidium oocysts in samples of raw surface water and wastewater. Appl. Environ. Microbiol. 67, 1097-1101. 
DOI: 10.1128/AEM.65.4.1578-1583.1999

YIN, J., Y. SHEN, Z. YUAN, W. LU, Y. XU, J. CAO (2011): Prevalence of the Cryptosporidium Pig Genotype II in Pigs from the Yangtze River Delta, China. PLoS One. 6, 1-4. DOI: 10.1371/journal.pone.0020738

YUI, T., T. NAKAJIMA, N. YAMAMOTO, M. KON, N. ABE, M. MATSUBAYASHI, T. SHIBAHARA (2014). Age-related detection and molecular characterization of Cryptosporidium suis and Cryptosporidium scrofarum in pre- and post-weaned piglets and adult pigs in Japan. Parasitol. Res. 113, 359-365.
DOI: $10.1007 / \mathrm{s} 00436-013-3662-2$

ZHANG, W., F. YANG, A. LIU, R. WANG, L. ZHANG, Y. SHEN, J. CAO, H. LING (2013): Prevalence and genetic characterizations of Cryptosporidium spp. in pre-weaned and post-weaned piglets in Heilongjiang Province, China. PLoS One. 8, 1-6.

DOI.org/10.1371/journal.pone.0067564

SHARMA, D., N. K. SINGH, H. SINGH, S. S. RATH, D. P. BLAKE: Genetička raznolikost unutar 18S rRNA i aktin-lokusa Cryptosporidium scrofarum (Apicomplexa: Cryptosporidiidae) pri invaziji domaćih svinja (Sus scrofa domesticus) u Indiji. Vet. arhiv 91, 269-276, 2021.

\section{SAŽETAK}

U ovom je radu istraživana genetička raznolikost Cryptosporidium scrofarum (syn Cryptosporidium pig genotype II) domaćih svinja (Sus scrofa domesticus) iz regije Punjab, Indija. Provedeno je umnožavanje 18S rRNA i lokusa aktin-gena pomoću ugniježđene PCR metode iz uzoraka pozitivnih na Cryptosporidium te su sekvencirani amplikoni. Filogenetska usporedba parcijalnog 18S rRNA gena pokazala je da su uzorci genetski najsličniji C. scrofarum izoliranom u drugim dijelovima svijeta. Također, usporedba sekvencija dijela lokusa genomskog aktina otkrila je novi genotip očuvan unutar izolata uzorkovanih u Indiji, ali različitih od drugih objavljenih sekvencija, upućujući na postojanje zasebnog indijskog genotipa.

Ključne riječi: aktin; Cryptosporidium scrofarum; genetička raznolikost; svinja; filogenija; $18 \mathrm{~S}$ rRNA 